\title{
Device Slipped
}

National Cancer Institute

\section{Source}

National Cancer Institute. Device Slipped. NCI Thesaurus. Code C62840.

Problem associated with the device moving or sliding from the intended position. 